\title{
Controlling Factors of Badland Morphological Changes in the Emilia Apennines (Northern Italy)
}

\author{
Paola Coratza * (D) and Carlotta Parenti \\ Department of Chemical and Geological Sciences, University of Modena and Reggio Emilia, Via Campi 103, \\ 41125 Modena, Italy; carlotta.parenti@unimore.it \\ * Correspondence: paola.coratza@unimore.it
}

Citation: Coratza, P.; Parenti, C. Controlling Factors of Badland Morphological Changes in the Emilia Apennines (Northern Italy). Water 2021, 13, 539. https://doi.org/ 10.3390/w13040539

Academic Editor: Csaba Centeri

Received: 29 December 2020

Accepted: 16 February 2021

Published: 19 February 2021

Publisher's Note: MDPI stays neutral with regard to jurisdictional claims in published maps and institutional affiliations.

Copyright: (c) 2021 by the authors. Licensee MDPI, Basel, Switzerland. This article is an open access article distributed under the terms and conditions of the Creative Commons Attribution (CC BY) license (https:// creativecommons.org/licenses/by/ $4.0 /)$

\begin{abstract}
Badlands are typical erosional landforms of the Apennines (Northern Italy) that form on Plio-Pleistocene clayey bedrock and rapidly evolve. The present study aimed at identification and assessment of the areal and temporal changes of badlands within a pilot area of the Modena Province (Emilia Apennines), where no previous detailed investigation has been carried out. For this purpose, a diachronic investigation was carried out to map the drainage basin and the drainage networks of the linear erosion features in the study area during the last 40 years, and to evaluate changes in badlands drainage basins morphometry and surface, land use and pluviometry. The investigation carried out indicated a general stabilisation trend of the badlands in the study area. In fact, a reduction in the bare surface area from $6187.1 \mathrm{~m}^{2}$ in 1973 to $4214.1 \mathrm{~m}^{2}$ in 2014 (31\%), due to an intensified revegetation process around the badland areas, has been recorded. This trend, in line with the results of research carried out in other sector of the Northern Apennines, is mainly due to intensive land use changes, mostly the increase in forest cover and the reduction of agricultural land, that occurred in the study area from the 1970s onwards.
\end{abstract}

Keywords: badlands; morphological changes; land use change; Emilia Apennines (Northern Italy)

\section{Introduction}

Soil erosion is one of the most significant land degradation processes worldwide and has produced diverse geomorphological effects in different environments according to anthropogenetic and climatic forcing.

Badlands are deeply and densely dissected accelerated erosional landforms often developed on unconsolidated or poorly cemented materials [1]. They are generally characterised by steep, unvegetated slopes, a high drainage density and high erosion rates. Badlands are similar to miniature fluvial systems, and it is possible to observe interconnections between hillslope processes and landforms [2]. The morphogenesis and evolution of badlands are complex and still under debate. Among the controlling factors suggested in the literature, those indicated as fundamental are as follows: (i) The lithology $[3,4]$ and physical, chemical and mineralogical properties (e.g., sediment size, clay mineralogy, Atterberg's limits, porosity and pore water chemistry) [5,6]; (ii) climatic factors such as strong seasonal humid/arid contrasts favoured by south-facing slopes [6-11]; (iii) the landscape morphology/topography, particularly the slope gradient, orientation and exposure [12]; (iv) anthropic activities such as deforestation for land reclamation, land levelling, cropland abandonment, extensive agriculture and pasture [13,14]. Moreover, badland areas are often characterised by scarce or absent vegetation cover [15-19], related to unfavourable climate conditions, and by the occurrence of mass wasting processes such as slides, earthflows, mudflows and creeping $[8,14,20,21]$.

Badlands are typically frequent in drylands [20,22-29], but they also occur in wetter areas (from semiarid to humid), with annual rain ranging from 400 to $1200 \mathrm{~mm} /$ year, often concentrated in the autumn after marked semiarid conditions during the summer period, as in the Mediterranean Basin [30-35]. 
Hillslope degradation is an important process that can have negative impacts on agriculture and terrestrial ecosystems as a whole [36], causing the loss and depletion of soil, decreases land productivity and accessibility, economic damage, risky conditions and environmental changes in the landscape [37-45]. On the other hand, it can also increase the geodiversity of a territory, contributing to its tourism development [14,46-48]. Moreover, spectacular erosion landforms (i.e., badlands) have important ecological functions and are considered hotspot areas of biodiversity [49]. The different phases of historical gully erosion can reflect significant environmental changes such as changes in climate and human-environment interactions [48]. During times of global change, it is of remarkable interest to trace the environmental changes in different terrains, including badlands, and to properly analyse and study these processes in order to plan effective strategies for landscape conservation and enhancement.

For the last 30 years there has been a growing scientific interest in badlands and, more in general, in gully erosion. This reflects the concern to increase knowledge of factors, controls, dynamics and impacts of badlands in the context of global change [39,44,50-52]. The study of Martinez-Murillo and Nadal-Romero [53] reviewed studies during recent decades on badlands, presenting a summary of the main specific research topics: origin, lithology, human activities and land use, vegetation, hydrology, piping, erosion and erosion rates, modelling and use of emerging technologies, reclamation and restoration, geoheritage and geotourism. Many studies have examined the effects of human activities and land use changes on badlands [54-61]. Farming systems and practices, such as development of livestock and croplands, rural abandonment and land levelling, can strongly affect the persistence and the evolution of badlands. In particular, land levelling is responsible for badland shrink in several parts of the world, as reported by Poesen [62]. Clarke and Rendell [56] highlight how the remodelling and levelling activities to increase agricultural productivity can cause the loss of badland landforms and an increase in soil erosion. Hillslope degradation in response of land use change, also promoted by agricultural policy, has been extensively documented in semi-arid regions, particularly in many areas of the Mediterranean Basin [35,56,63-69]. Reforestation is also blamed to play an active role on landscape transformation and particularly in decreasing erosion rates in badland areas [35,70-73]. The relationship between changes in rainfall patterns (annual precipitation, intensity and inter-annual variability) and badland inter-rill erosion has received attention as well [56,66,67,74-80].

In Italy, badlands are spread widely and discontinuously in areas of the Apennines mountain chain and Sicily, where Plio-Pleistocene marine clayey and marly terrains outcrop [81]. In the Italian literature, the investigation of badland landforms and landscapestheir identification, characterisation, and temporal and spatial variation-dates back to the beginning of the last century and is mainly concentrated on central and southern parts of Italy $[2,6,11-14,17,23,28,49,55,67,80-102]$.

Badlands consisting of Pliocene and Pleistocene claystone are widespread in the preApennine hills in the Emilia Romagna region, but, apart from the studies by Bucciante [6] and Farabegoli and Agostini [87], no recent and detailed work has been conducted. The local erosion rates have been very high in this area, causing the development of widespread badland landforms, accompanied by hazardous processes, such as the retrogression of badland scarps and rapid soil depletion. The Modena Apennines are widely affected by intense hillslope degradation, and typical badland examples are observed in the hilly area between Fiorano and Marano sul Panaro. According to the Modena Province-Coordinated Territorial Plan (PTCP), badlands are divided and mapped according to their landscape value, as:

- Type A or peculiar badlands (type A sensu [17,83]), characterised by sharp and dissected landforms with knife-shape slopes, sparse vegetation and high drainage. This type of badland has a high intrinsic landscape value, and all interventions and activities that could alter or compromise the conditions of the places, the morphogenetic or biological processes, or the perception of the landscapes are forbidden [103]; 
- Type B or typical badlands (type B sensu $[17,83]$ ), characterised by gentle slopes affected by recurrent surficial slides and mudflows and a less-dense drainage system. For this type of badland, with a medium landscape value, some anthropogenic activities (e.g., the installation of telecommunication lines and systems, and systems for water supply) in the surrounding areas are allowed;

- $\quad$ Type C or pseudo-badlands, characterised by a gentle morphology, with little-to-no landscape value. Anthropogenic activities are allowed in these areas, but measures to mitigate the impacts on the landscape should always be taken;

In Modena Province, $8 \%$ of the badlands are Type A and cover an area of $3.6 \mathrm{~km}^{2}$, $48.2 \%$ belong to Type B and cover $10 \mathrm{~km}^{2}$, and $43.8 \%$ belong to Type $C$ and cover $10.1 \mathrm{~km}^{2}$.

Starting from these premises, the present study focuses on badlands of a pilot area in the Modena Province (Emilia Apennines, Northern Italy), representative of the morphoevolution and degradation processes that affect hilly areas of the Emilia Apennines. The study area is part of the industrial district of Sassuolo-Fiorano-Maranello, the largest tile making district in the world, that faced significant land use changes in the past century. Moreover, the area represents a growing tourist attraction due to the high aesthetic value of hilly landscapes and to the presence of the best developed and largest mud volcano field of Italy. As mentioned above, no previous systematic studies on badlands in Emilia Apennines have been conducted. Thus, the main aims of this study are the: (i) Identification, morphometrical characterisation and mapping of spatial and temporal changes of badlands; (ii) identification and characterization of the main geo-environmental features, such as topographic aspect, climate, and human induced land use changes, to detect the controlling factors in the morphodynamics of badlands in the study area.

For this purpose, a diachronic investigation is carried out, mapping the drainage basin and the drainage networks of each badlands area over the last 40 years, and evaluating changes in badland drainage basins morphometry and surface, land use and pluviometry. The obtained results are compared with studies on badlands in Apennines and in the central Mediterranean regions.

\section{Study Area}

The study area, located on the foothills of the Northern Apennines (Municipality of Fiorano Modenese, Modena Province, Italy) has an extent of about $10 \mathrm{~km}^{2}$ and an elevation ranging from 143 to $308 \mathrm{~m}$ a.s.l. (Figure 1). The area is; therefore, a low-hill territory, belonging to the River Secchia catchment. The Torrente Fossa, the main stream channel in the study area, is a right tributary of the River Secchia and flows in a SW-NE direction, collecting the water of its left tributaries, Rio Chianca and Rio delle Salse.

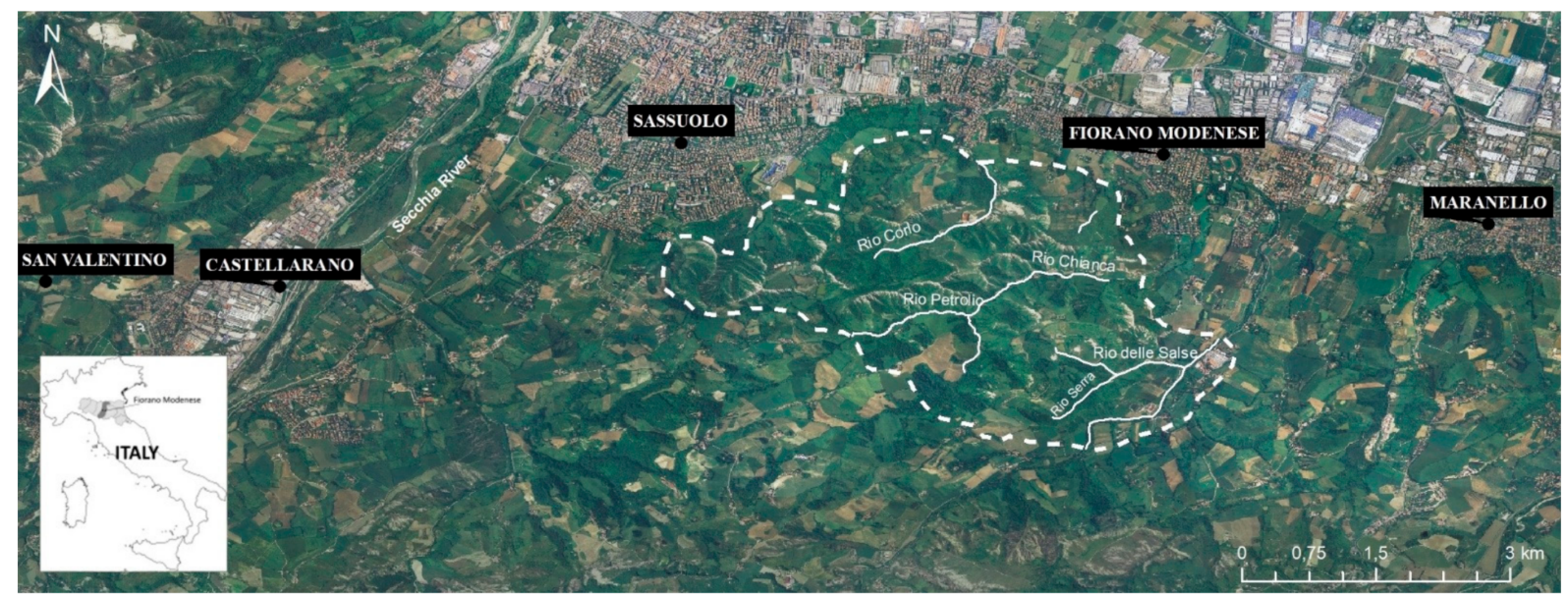

Figure 1. Location of the study area (white dashed line) and localities cited in this paper (@2017 Google). 


\subsection{Climatic Setting}

The climate of the area is defined as temperate, a mild temperate climate (Cfa) according to the Köppen classification [104]. An arithmetic mean of climate data for the period 1954-2018, related to three significant stations in the surrounding regions of the study area (San Valentino, Castellarano and Sassuolo cf. Figure 1), are summarised in Table 1. The mean annual rainfall is around $800 \mathrm{~mm}$. Rainfall is concentrated in the spring and autumn months, with a maximum precipitation in November at about $90 \mathrm{~mm}$; conversely, the summer months are hot and dry, with a minimum precipitation in July at only $39 \mathrm{~mm}$ (Figure 2a). The mean annual temperature is about $13{ }^{\circ} \mathrm{C}$. In July, the hottest month, the temperature reaches $29^{\circ} \mathrm{C}$ in July, the hottest month, and $2{ }^{\circ} \mathrm{C}$ in January, the coldest (Figure 2b).

Table 1. Climate data of the study area.

\begin{tabular}{cc}
\hline & $\mathbf{1 9 5 4 - 2 0 1 8}$ \\
\hline Mean annual rainfall $(\mathrm{mm})$ & 840 \\
Minimum annual rainfall $(\mathrm{mm})$ & 449 \\
Maximum annual rainfall $(\mathrm{mm})$ & 1160 \\
Absolute minimum monthly rainfall $(\mathrm{mm})$ & 39 (July) \\
Absolute maximum monthly rainfall $(\mathrm{mm})$ & 93 (November) \\
Mean annual temperature $\left({ }^{\circ} \mathrm{C}\right)$ & 13 \\
Minimum monthly temperature $\left({ }^{\circ} \mathrm{C}\right)$ & 2 (January) \\
Maximum monthly temperature $\left({ }^{\circ} \mathrm{C}\right)$ & 29 (July) \\
\hline
\end{tabular}
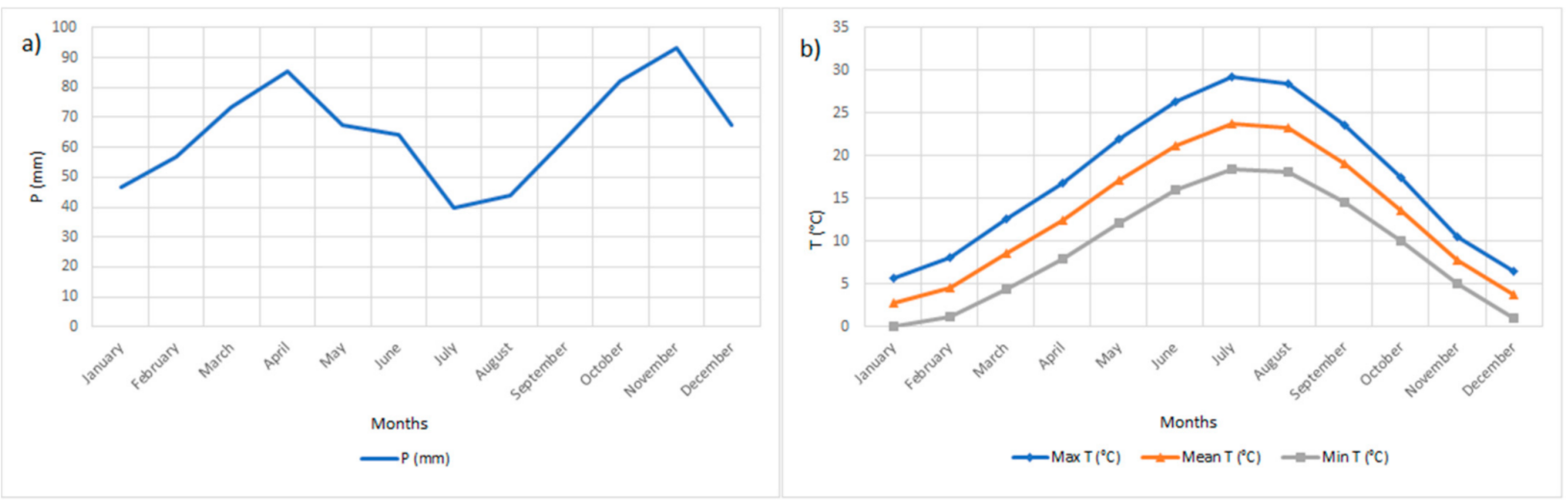

Figure 2. (a) Average monthly precipitation for the study area; (b) average monthly maximum, minimum and mean temperature of 1954-2018.

\subsection{Geological Setting}

From a geological viewpoint, the area is located in the Modena Apennine margin, where the outcropping units reflect the most recent (since the Upper Eocene) geological history of the rising Apennine chain (Figure 3). In particular, marine silty-clayey rock types belonging to the Argille Azzurre Formation (Lower Pliocene-Lower Pleistocene) extensively crop out [105]. They are marly clays, grey and blueish-grey clayey and silty marls, cropping out in medium-to-thin layers, with joints hardly visible owing to bioturbation. Discontinuous, thin, laminated layers of fine biocalcarenites and yellowish siltites are found locally $[105,106]$. The carbonate content is quite low $(25-30 \%)[107]$, and the main components are kaolin and montmorillonite [108]. The general setting of the strata shows a NW-SE strike, with an $8^{\circ}$-to- $40^{\circ} \mathrm{NE}$ dip. In the SW part of the study area, the Termina Formation (Tortonian-Lower Messian) crops out. The Termina Formation is composed of greyish clayey marl characterised by undistinguished stratification and by the presence of bioclasts, biosoma and glauconite, intercalated by thin layers of fine sandstone. Continental 
Quaternary deposits, which belong to the Modena Unit sediments dating from the sixth century CE, crop out along the Torrente Fossa riverbed. This unit comprises gravel deposits turning to alluvial terrace sand and silt deposits $[105,106]$. Corresponding to the Salse di Nirano Natural Reserve, there are sediments belonging to the emissions of Salse. They are considered Quaternary deposits and are composed of "mud flow" locally complemented by debris related to the upwelling of water and hydrocarbons.

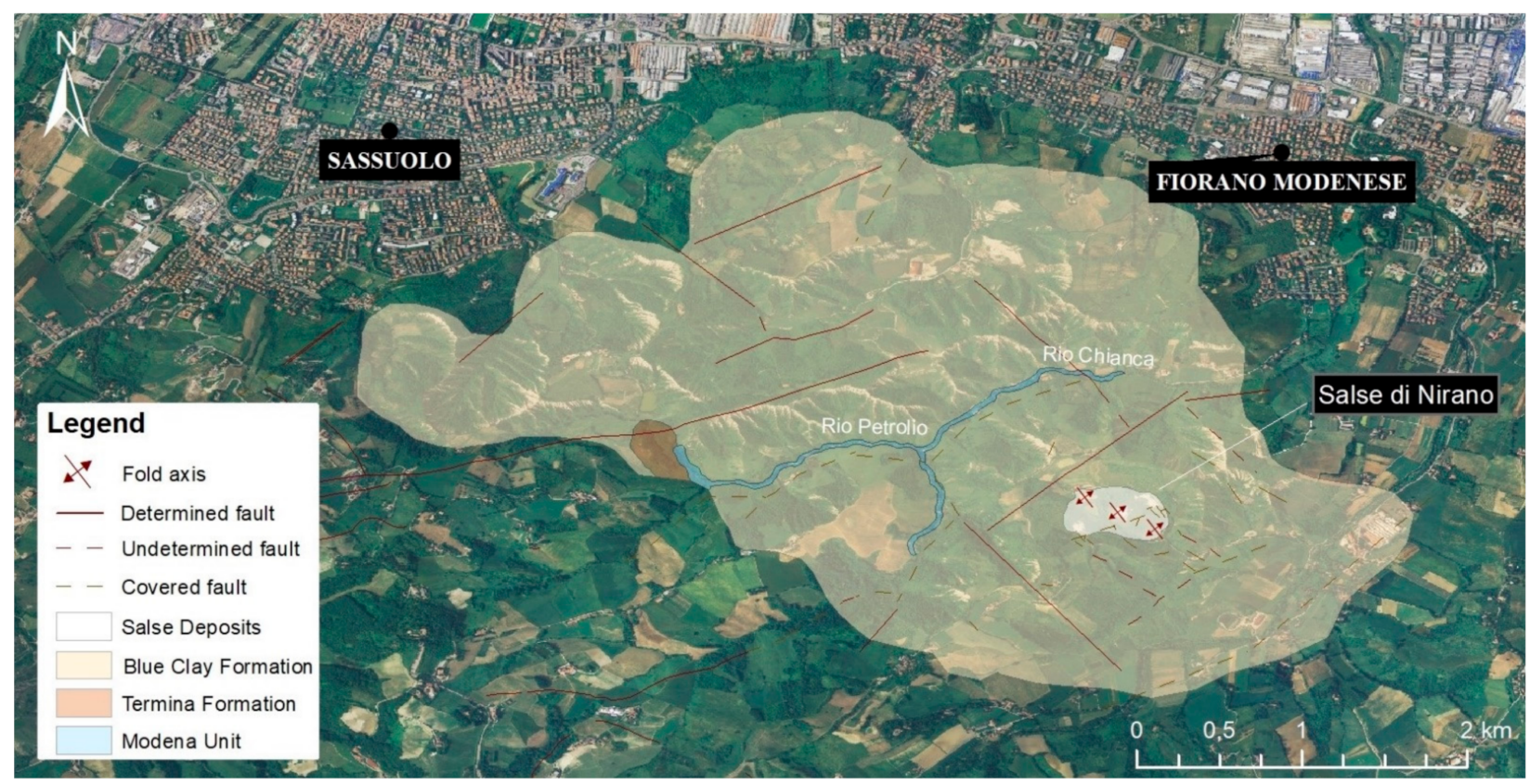

Figure 3. Litho-structural sketch of the study area.

From a tectonic viewpoint, the study area is located approximately $2 \mathrm{~km}$ southwest of the active Pedo-Apennine thrust. An anticline, folding the Pliocene-Early Pleistocene claystone, crosses the area, with its major axis trending NW-SE. Two main families of steep, nearly perpendicular, tectonic discontinuities (high angle faults and/or fractures) are oriented with NW-SW direction and, orthogonal to the latter, with SW-NE and ENEWSW direction.

\subsection{Geomorphological Outlines}

The geomorphological features of the study area are determined by the widespread presence of clay. The main geomorphological processes and related landforms are associated to mass movements and surface runoff. Landslides are mainly ascribable to shallow earth slides and earth flows, in most cases affecting cultivated fields. Many landslide deposits along the Rio Serra and Rio delle Salse valleys have been colonised by spontaneous vegetation, which has contributed to their stabilisation. Solifluction is a secondary process particularly widespread in the northern part of the area, particularly in slopes with fine grain size lithologies and bare of vegetation, where it has been favoured by creep due to grazing. Landforms and deposits due to running waters are particularly widespread. The alluvial deposits are limited in the central region of the study area in correspondence with Rio del Petrolio and Rio Chianca. Due to the mutual interaction between gravitational processes and running water action, a remarkable badland morphology, developed on slopes constituted by the Argille Azzurre Formation, characterises this area (Figure 4). In fact, according to PTCT, Type A badlands make up more than $40 \%$, covering an area of $1.4 \mathrm{~km}^{2}$, while Type B and C badlands represent $29 \%$ each, covering 0.5 and $0.4 \mathrm{~km}^{2}$, respectively. Landslides and earth flows can contribute to the regression of the badlands' slopes and can fill the drainage network. 

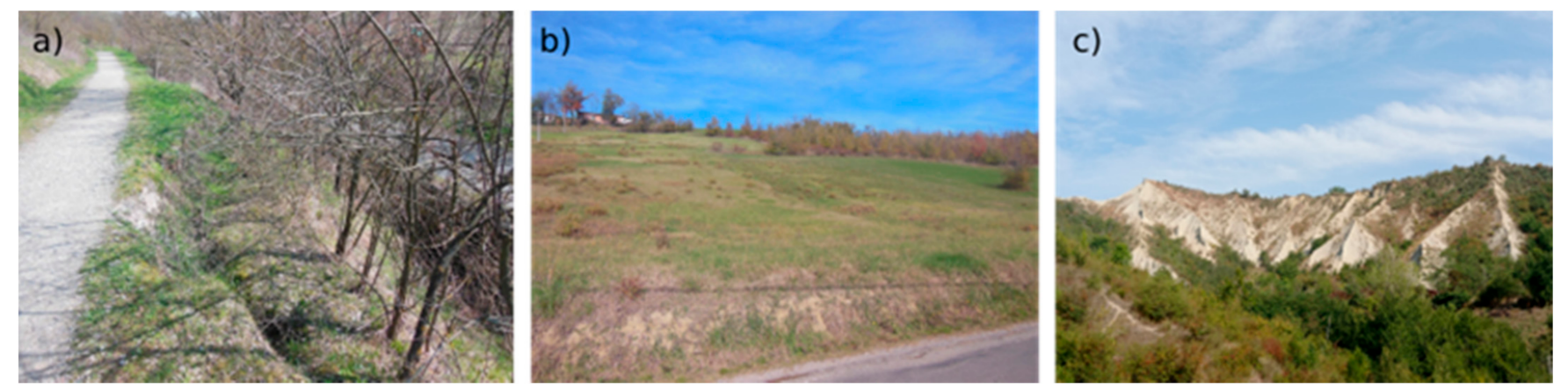

Figure 4. Main geological and geomorphological features of the study area: (a) Active landslide; (b) solifluction characterising the Argille Azzurre Formation; (c) badland morphology characterising the Argille Azzurre Formation.

\section{Materials and Methods}

Initially badlands were mapped on 1:5000 topographical maps by aerial photo and satellite image interpretation and field visits, allowing an inventory map of badlands to be constructed. In our study, we consider only Type A badland $[17,83]$ and every little horseshoe type hydrographic unit characterised by bare soil or signs of intense denudations were mapped.

The morphological evolutionary trend of the badlands in the study area was evaluated according to the different steps described below.

\subsection{Multitemporal Analysis of Aerial Photos and Satellite Images and Mapping of Badlands' Drainage Basin Changes}

The multitemporal mapping of the drainage basins of each badland area, with particular reference to the badlands' head retreats and sidewall failures, was performed in GIS (ESRI software ArcGis 10.2.1, ArcMap) through manual delineation method. Gully walls and headcuts were digitalized on screen and on orthophotographs and satellite images with appropriate and comparable scales (Table 2). Therefore, images dated to 1954 and 1981, with non-comparable scales, were excluded from the mapping. Considering this source data, with a resolution of $0.5 \mathrm{~m}$, the expected error is of $\pm 2 \%[11,103]$. Subsequently, the area (A) of each drainage basin and its bare surface was calculated and uploaded into a geodatabase, and the percentages of surface variations throughout the investigated periods were calculated with respect to the initial surface area size in order to compare their evolution and perform the succeeding morphometric analysis.

Table 2. Cartographic documents examined. GAI: Aerial Italian Group; RER: Emilia-Romagna Region; GN: Geoportale Nazionale website; AGEA: Agenzia per le Erogazioni in Agricoltura; TeA: Consorzio Telerilevamento Agricoltura; B/W: Black and white; C: Colour.

\begin{tabular}{ccccc}
\hline Type & Year & Scale & Flight & Color \\
\hline Aerial photos & 1954 & $1: 66,000$ & Volo GAI & B/W \\
Aerial photos & 1973 & $1: 15,000$ & Volo RER & B/W \\
Aerial photos & 1981 & $1: 33,000$ & Volo Romagna & B $/ W$ \\
Orthophotos & 1988 & $1: 10,000$ & National Web Map Service & B $/ W$ \\
Orthophotos & 1996 & $1: 10,000$ & National Web Map Service & B/W \\
Orthophotos & 2006 & $1: 10,000$ & National Web Map Service & $\mathrm{C}$ \\
Orthophotos AGEA & 2008 & $1: 10,000$ & National Web Map Service & $\mathrm{C}$ \\
Orthophotos AGEA & 2011 & $1: 10,000$ & Regione Emilia-Romagna Web Map Service & $\mathrm{C}$ \\
Orthophotos TeA & 2014 & $1: 10,000$ & . &
\end{tabular}

\subsection{Morphometric and Multiparametric Analysis}

The drainage network in the digitalised basins was reconstructed through the aerial photointerpretation of two pairs of orthophotos from the years 1973 and 2014 that show 
the most significant changes in the badland area and morphology. The stream network was digitalised in GIS, through manual delineation method; the lengths of the channels (L), the number, and the stream hierarchy were identified; and the following morphometric indices were calculated: The drainage density (D) and the direct bifurcation ratio (Rdb). These indices are related to the characteristics of the hydrographic system and depend on the erosion rate. The D parameter is the sum of the lengths of all the streams and rivers in a drainage basin $(\Sigma L)$ divided by the total area of the drainage basin $(A)[109,110]$. The intensification of the precipitation and slope acclivity cause the $\mathrm{D}$ to increase. The higher the $\mathrm{D}$, the higher the erosion rate for the ground. The direct bifurcation ratio is the ratio of the number of stream branches of a given order $(\mathrm{Ndu})$ to the number of stream branches of the next higher order $(\mathrm{Nu}+1)$ [109-111].

In order to correlate different factors, a multiparametric analysis was performed, taking into account the following parameters: The direct bifurcation ratio, drainage density, slope exposure, and basin evolution typology.

\subsection{Pluviometric Data and Land Use}

Although the pluviometric data were fragmented for the study area, three measuring stations adjacent to the area, and located at San Valentino (314 $\mathrm{m}$ a.s.l.), Sassuolo (121 $\mathrm{m}$ ) and Castellarano $(135 \mathrm{~m})$, were taken into consideration and an arithmetic mean of data from these stations was used for analysis. The dataset covers the period 1954-2018. In order to better understand the role played by precipitation variability in badland development, total annual and monthly precipitation data over a period of 60 years were computed. Moreover, the rainfall intensity, maximum number of consecutive dry days and maximum number of consecutive wet days were calculated. According to several authors $[45,66,76,112]$, daily rainfall $>10.0 \mathrm{~mm}$ can be considered the threshold at which runoff commences in semiarid environments. Accordingly, pluviometric events $>2.0,>10.0$ and $<30.0$, and $>30.0 \mathrm{~mm}$ were considered, and the trend from 1954 to 2018 was analysed. Finally, the average annual precipitation over 10-year periods was then correlated with the results obtained by the analysis of the evolutionary trend of the badland area and the multitemporal photointerpretation analysis.

Because land use changes and variation in vegetation cover are possible driving factors for badland evolution, land use changes were examined using two datasets for 1994 and 2014 provided by the Geoportale della Regione Emilia-Romagna, and the percentages of the major land use classes, according to the CORINE Land Cover, were calculated.

\section{Results and Discussion}

\subsection{Multitemporal Analysis and Mapping of Badland Areas}

The multitemporal photointerpretation allowed the identification of the surface-area changes caused by water runoff over the last 50 years. In 1954, the badlands were characterised by a dense network of deep incisions, and steep and bare slopes with sharp, knife-edge ridges. In 1973 and 1981, the vegetation cover increased, and rills and gullies were less evident. Significant changes cannot be recognised in the aerial photos of 1988/89 and 1994 due to their small scales and black and white colours. From 2003 to the present, the vegetation cover has colonised the foot of the slopes, and a general trend of decreasing bare surface areas and a progressive increase in vegetation growing upward can be observed. Moreover, the bottom of the gullies has frequently become filled with flow deposits over the last 50 years.

The analysis of the orthophotos spanning 1973 to 2014 allowed the mapping and digitalisation of 55 drainage basins (Figure 5). Inside each basin, the segment of furrows was traced for the years 1973 and 2014, showing the most significant changes in badland surface area (Figure 5). The multitemporal landform mapping provided information about badland changes and evolution in time and space. 


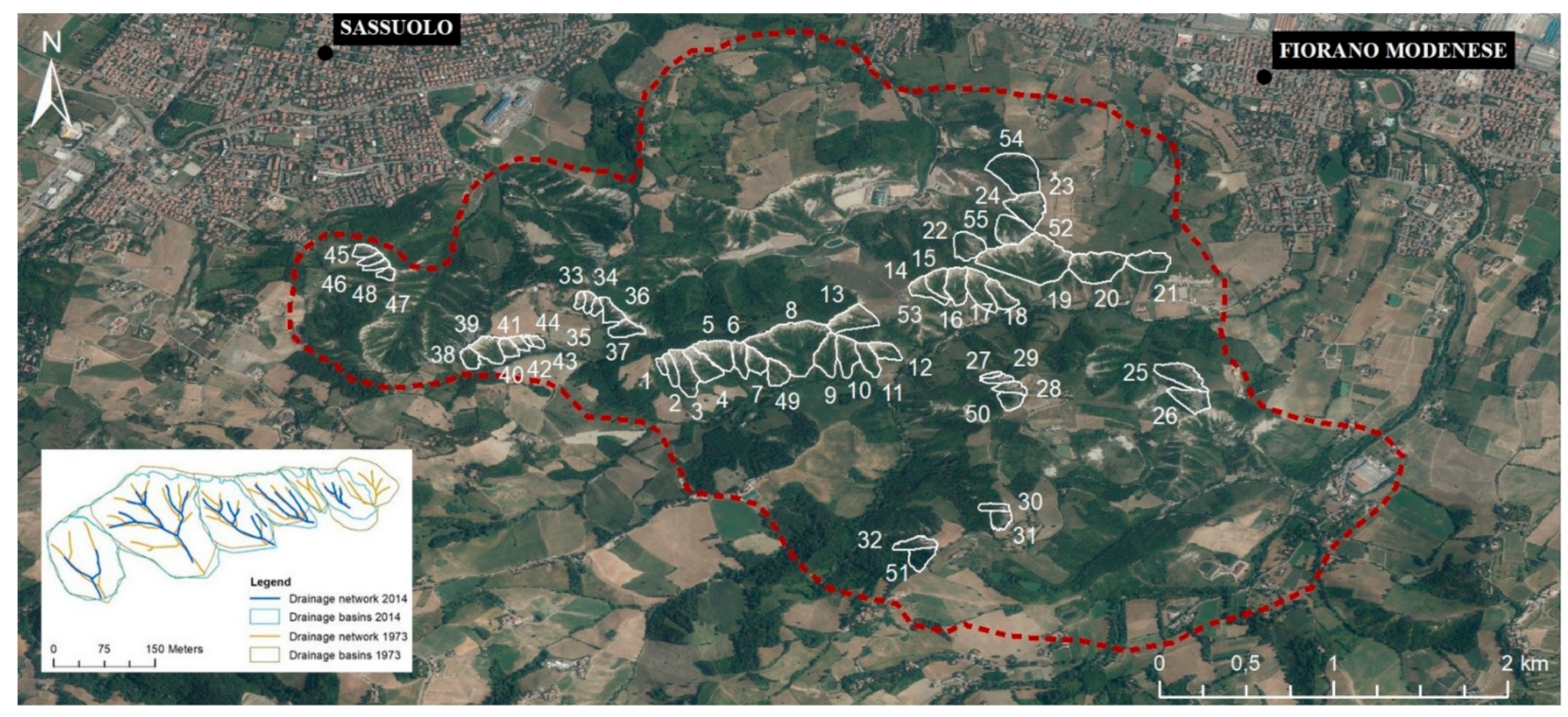

Figure 5. Badlands inventory map (white line) in the study area (red dashed line). The box shows an example of the area variation over a 40-year period and the segment of furrows traced.

Observing the spatial distribution of badlands, it can be noticed that $60 \%$ of badlands is aligned preferentially along an ENE-WSW direction, perpendicular to the anticline which cross the area, while the remaining $40 \%$ is aligned preferentially parallel to the anticline with the major axis trending NW-SE, documented in local geological maps.

On average, the recorded trend highlighted a moderate reduction in the bare surface area from $6187.1 \mathrm{~m}^{2}$ in 1973 to $4214.1 \mathrm{~m}^{2}$ in $2014(31 \%)$, due to an intensified revegetation process around the badland areas, while the total badland area did not show a significant modification, from $575,778 \mathrm{~m}^{2}$ in 1973 to $583,565 \mathrm{~m}^{2}$. In fact, the increase of about $1.3 \%$ in the total badland area is in line with expected error related to orthophotos resolution and digitalization process.

In particular, for a 40-year period in the study area, it can be observed that:

- In 26 basins, there is no evidence of significant evolution of the upper margin of the badland; the upper margin is indeed apparently stable;

- In 10 basins, the upper margin is moving downward because of the vegetation preventing the erosion;

- In 11 basins, the ridge of the badlands is affected by a regression of the margin;

- Four basins are visible only in the aerial photos of 1973 and not in the orthophotos of 2014: This is due to intensified revegetation processes;

- Four basins are visible only in the orthophotos of 2014 and not in the aerial photos of 1973.

The changes in the bare surface area may suggest that, in the study area, the revegetation process is more intense than the erosion one.

\subsection{Morphometric and Multiparametric Analysis}

Regarding the morphometric analysis, the data relating to the geometric parameters of the badland basins in 1973 and 2014 can be summarised as follows:

- D fluctuated between 0.018 and $0.064 \mathrm{~m} / \mathrm{m}^{2}$ in 1973 and 0.006 and $0.044 \mathrm{~m} / \mathrm{m}^{2}$ in 2014. The average values were $0.04 \mathrm{~m} / \mathrm{m}^{2}$ (in 1973) and $0.02 \mathrm{~m} / \mathrm{m}^{2}$ (in 2014) (Figure 6). In 1973, the maximum value was $0.064 \mathrm{~m} / \mathrm{m}^{2}$, and the minimum, $0.018 \mathrm{~m} / \mathrm{m}^{2}$; in 2014, the maximum was $0.044 \mathrm{~m} / \mathrm{m}^{2}$, and the minimum, $0.006 \mathrm{~m} / \mathrm{m}^{2}$. The averages were $0.04 \mathrm{~m} / \mathrm{m}^{2}$ (in 1973) and $0.02 \mathrm{~m} / \mathrm{m}^{2}$ (in 2014);

- Rdb fluctuated between 2 and 6 in 1973 and between 2 and 5 in 2014, showing that the hydrographic system is not very articulated. The maximum value in 1973 was 6 , 
and the maximum in 2014 was 5; the minimum value was 2 in both 1973 and 2014 (Figure 7).

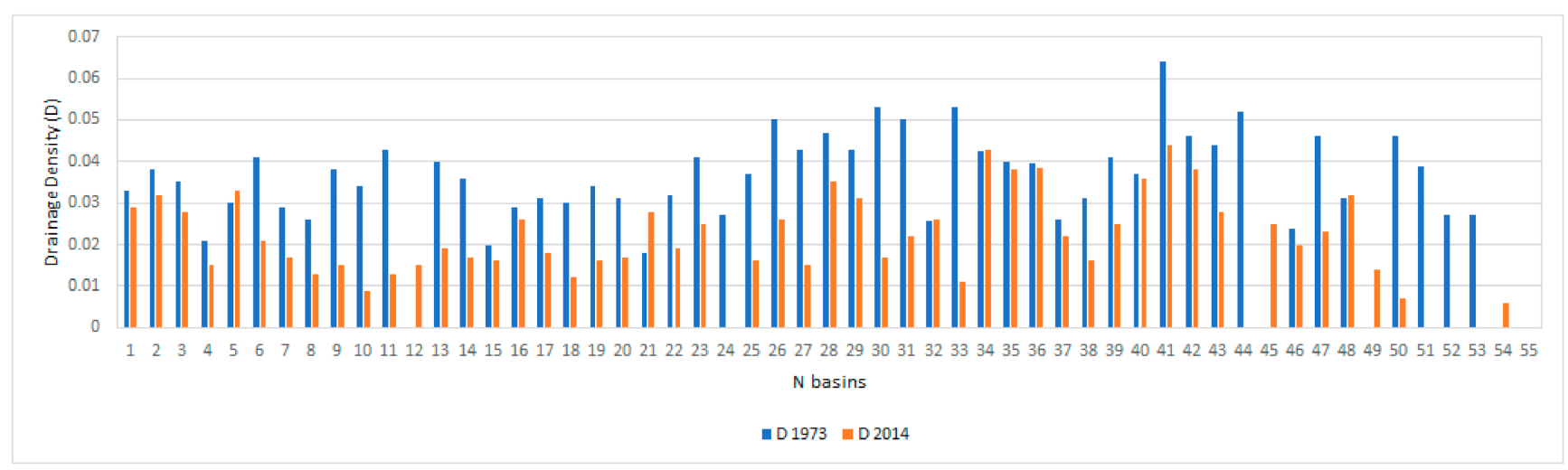

Figure 6. Variation of drainage density (D) values in 1973 (in blue) and in 2014 (in orange).

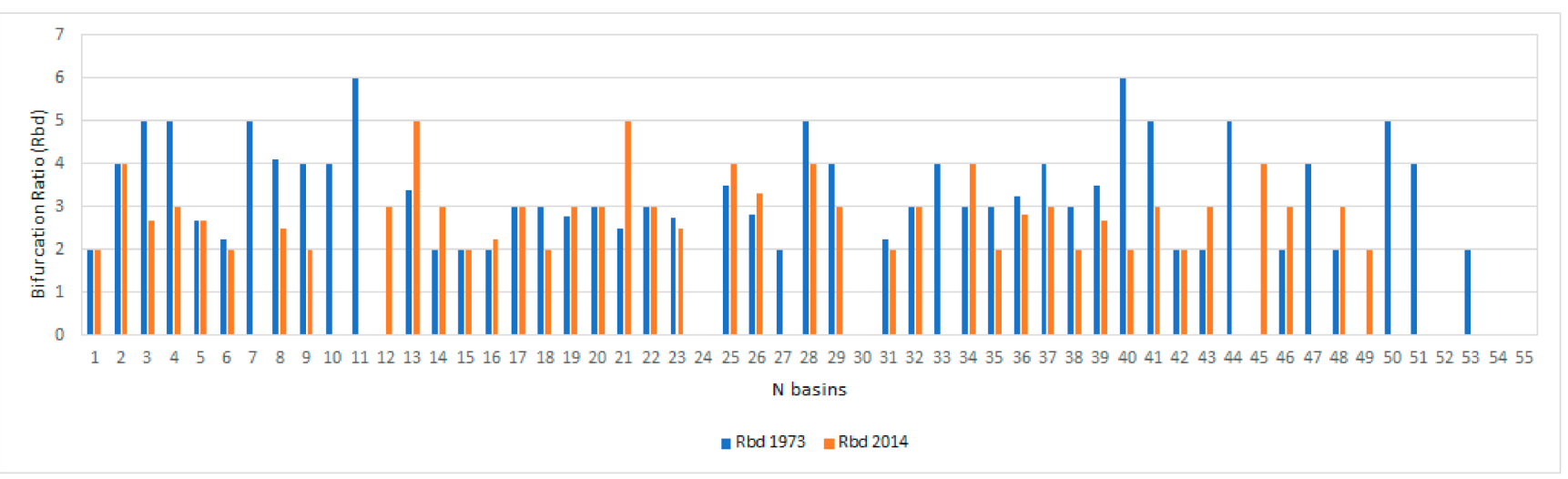

Figure 7. Variation of Bifurcation Radio (Rdb) values in 1973 (in blue) and in 2014 (in orange).

Comparing the values of D in 1973 and in 2014, it can be noticed that D is generally decreasing through time, indicating a decreasing erosion rate for the ground. This could be mainly due to the decreasing total length of the channels of the hydrographic system $(\Sigma \mathrm{L})$ and not to the variation of the badland area extent. There was an increase in D in only five basins-5, 21, 32, 34, and 48 .

Comparing the values of $\mathrm{Rdb}$ in 1973 and in 2014, it can be observed that the $\mathrm{Rdb}$ values are generally decreasing, which means that the hydrographic systems are not so articulated and the erosion rate is decreasing. However, in 11 basins $(13,14,16,19,21,25$, $26,34,43,46$, and 48), Rbd is increasing, and the values did not change in nine basins $(1,2$, $5,15,17,20,22,32$, and 42).

Finally, we evaluated the correlation between the Rbd parameter and the D parameter for both years (the D values increased a hundred times) (Figure 8). Both D and Rdb tended to decrease over time, although with differently distributed values. In particular, only in nine basins (numbers 8, 9, 18, 23, 27, 28, 29, 33, and 41) there was a significant decrease in both $\mathrm{D}$ and $\mathrm{Rdb}$; in four basins (numbers 3, 4, 40, and 47), Rdb decreased significantly, unlike D, which showed a limited decrease; in seven basins (numbers 1, 2, 15, 17, 20, 22 , and 42), D decreased significantly, but the corresponding Rdb values do not show variations between the two years considered; finally, the increase in Rdb was also related to an increase in D only in three basins, namely, numbers 21,34 , and 48.

The data obtained were then correlated with the type of evolution of badlands and with slope aspect. Therefore, only basins characterised by significant evidence of evolution through time were considered. In 11 basins, the scarp of the badlands was affected by a regression, with the Rbd values showing a random trend and D values decreasing (showing 
a possible correlation). In 10 basins, the upper margin of the badlands is moving downward because of the presence of the vegetation, and the Rbd and D values have random trends, showing no correlation between the evolution typologies and the variation of parameters over time.

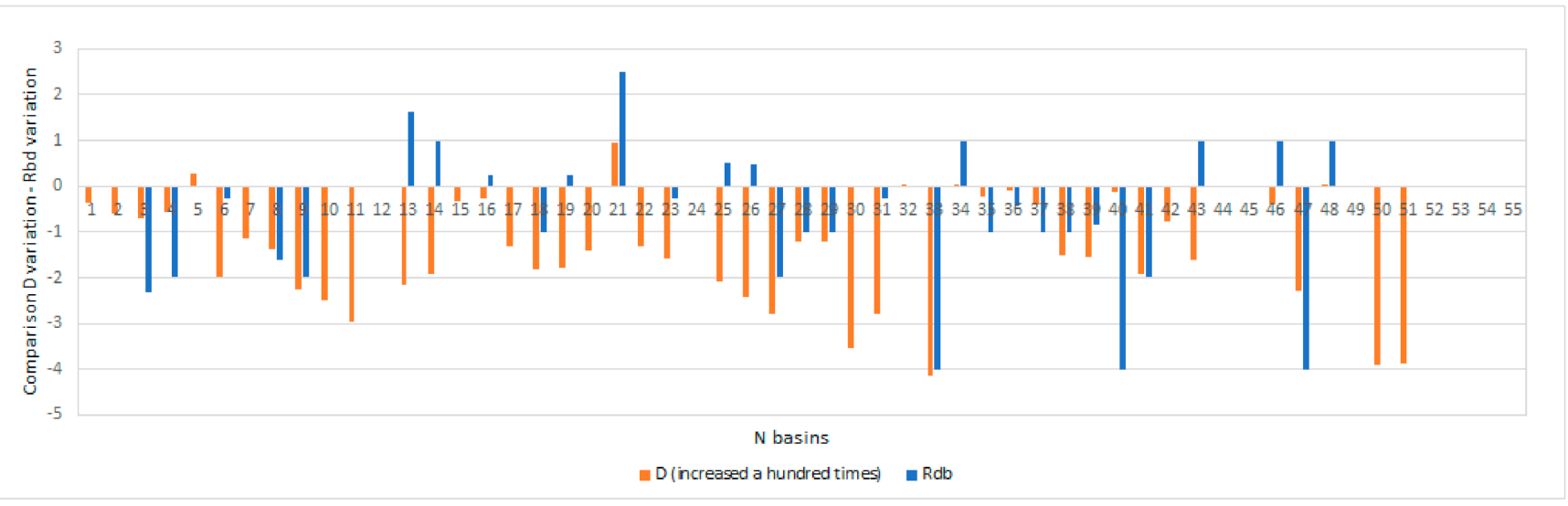

Figure 8. Comparison between D values in 1973 and D values in 2014 (increased a hundred times) (in orange) and differences between Rbd values in 1973 and Rbd values in 2014 (in blue) (y axis) and number of basins (x axis).

The slope exposure does not seem to have particularly influenced the evolution of the badlands. In fact, $69 \%$ of badlands form preferentially on SW and S-facing flanks $\left(135^{\circ}-225^{\circ}\right)$; of the 11 badlands that show a regression of the upper margin, five basins are exposed to western directions, five to a southern direction and only one to a northern direction (Figure 9). On the other hand, all 10 basins that show a revegetation process are exposed to southern directions.

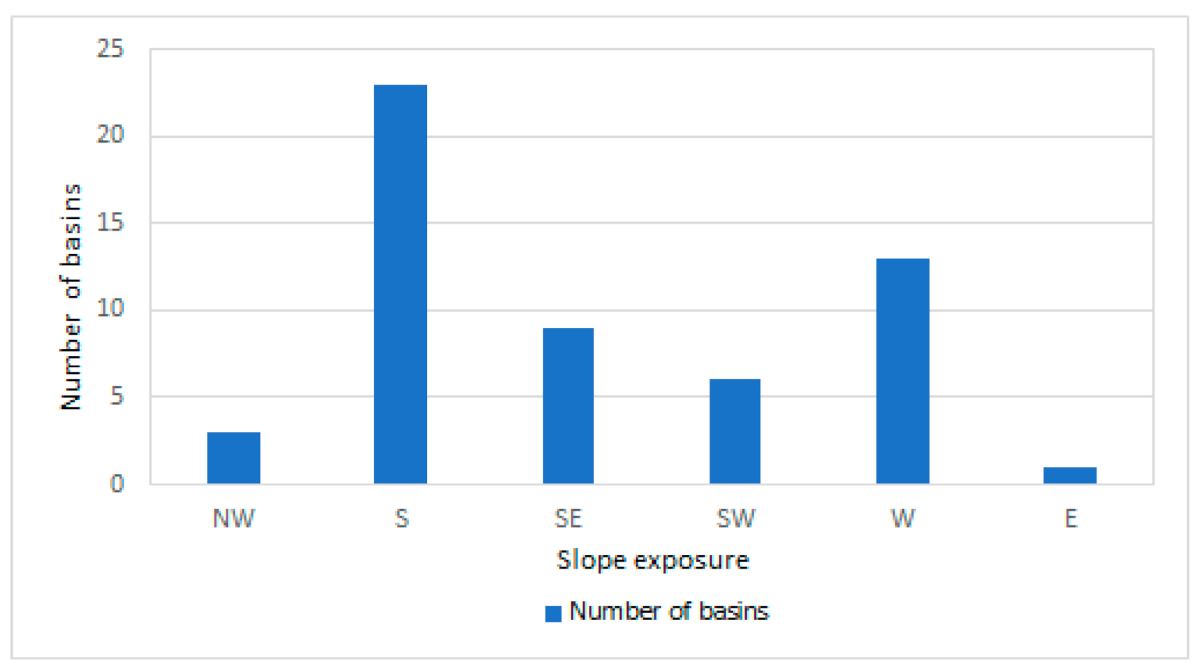

Figure 9. Relationship between the slope aspect direction and mapped badlands in the study area.

\subsection{Analysis of Pluviometric Data and Land Use Changes}

The analysis of the annual precipitation during the period 1954-2018 showed a general decreasing tendency for the average annual precipitation, although the decreases were very low and characterised by a sinusoidal trend (Figure 10a); this is consistent with the results reported by several authors on long-term climate variability in Italy [113-118]. A general decrease in rainfall intensity ( $\mathrm{mm} /$ rain day) also occurred during the period (Figure 10b). Nevertheless, the decrease in intensity was less than that in total annual precipitation. From the trend analysis of events $>2.0,>10.0$ and $<30.0$, and $>30.0 \mathrm{~mm}$, it emerges that a significant decrease in pluviometric events $>2.0,>10.0$, and $>30.0 \mathrm{~mm}$ has occurred 
(Figure 11), reflecting a general decrease in rainfall intensity and total annual precipitation. No significant trend was recorded for $>30.0 \mathrm{~mm}$ pluviometric events.

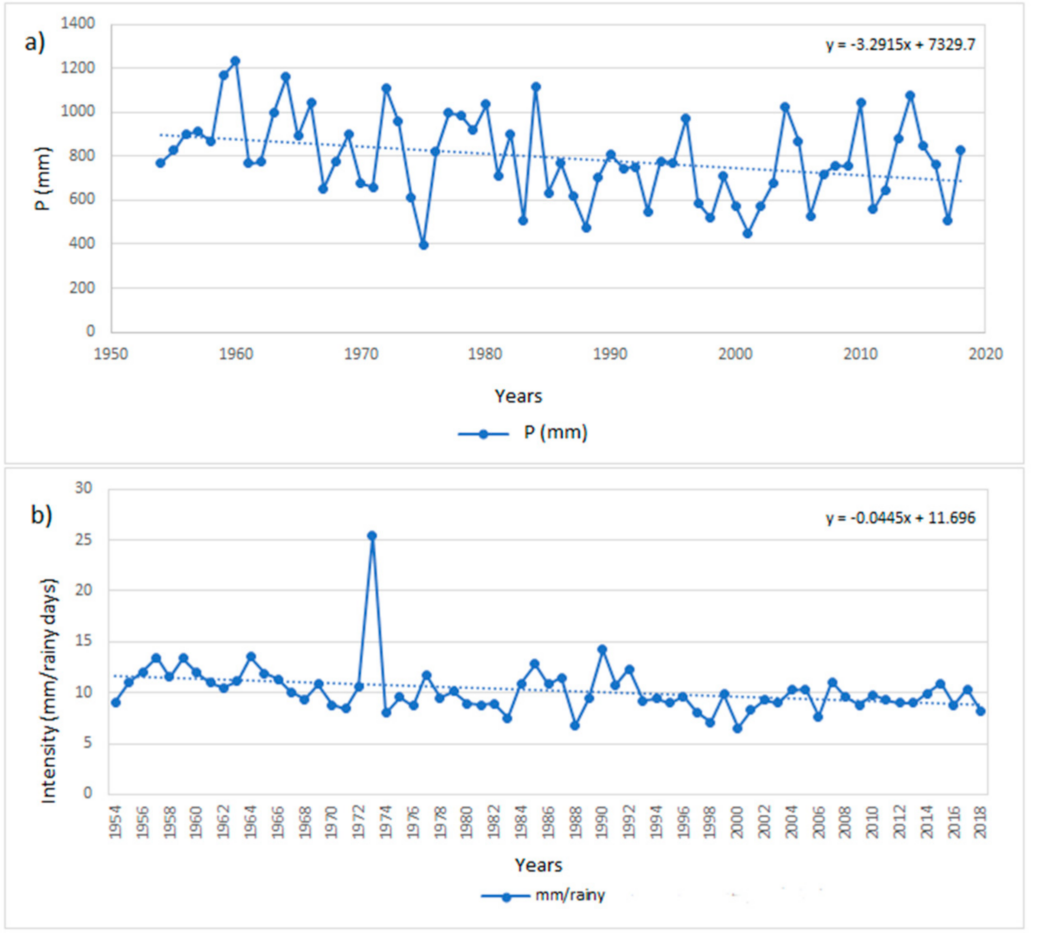

Figure 10. Pluviometric pattern for the study area: (a) Distribution of average annual precipitation during the observation period; (b) annual intensity ( $\mathrm{mm} /$ rain day).

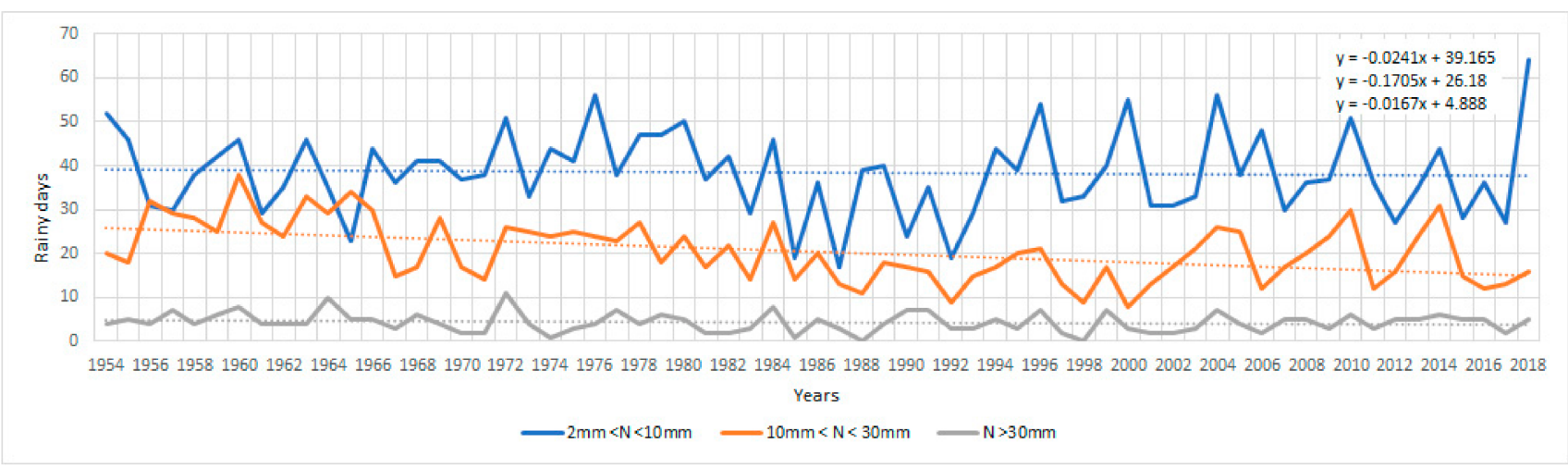

Figure 11. Total annual number of rainy days $>2 \mathrm{~mm},>10 \mathrm{~mm}$ and $<30 \mathrm{~mm}$, and $<30$ during 1954-2018.

In order to evaluate the role of dry/wet cycles, the maximum numbers of consecutive dry and wet daily events were calculated. The analysis shows a slight increase in consecutive wet days and decrease in consecutive dry days. This trend is in line with the bare surface area reduction recorded for the study area. In fact, a substantial decrease in the amount and frequency of rainfall tend to reduce the effectiveness of rilling, leading to less-intensive dynamics for the soil-erosion process.

The analysis of the average annual precipitation over 10-year periods (Figure 12) and of the results obtained by multitemporal photointerpretation analysis showed that, in 1954-1973, the variation of the average annual precipitation is represented by a decrease of about $15 \%$, accompanied by an increment in vegetation, as revealed by the multitemporal photointerpretation analysis. In 1973-1983, the average annual precipitation decreased by about $9 \%$, and the analysis of the evolutionary trend of the badland areas revealed 
that in $7 \%$ there was a retrogression of badland scarps by about $9 \mathrm{~m}$. No significant differences were detected in the period 1983-1993, while an increase of $15 \%$ in average annual precipitation was recorded in the subinterval 1994-2013. In this time period, $15 \%$ of the badlands were characterised by active retrogressive movement, which may be related to the precipitation increase recorded.

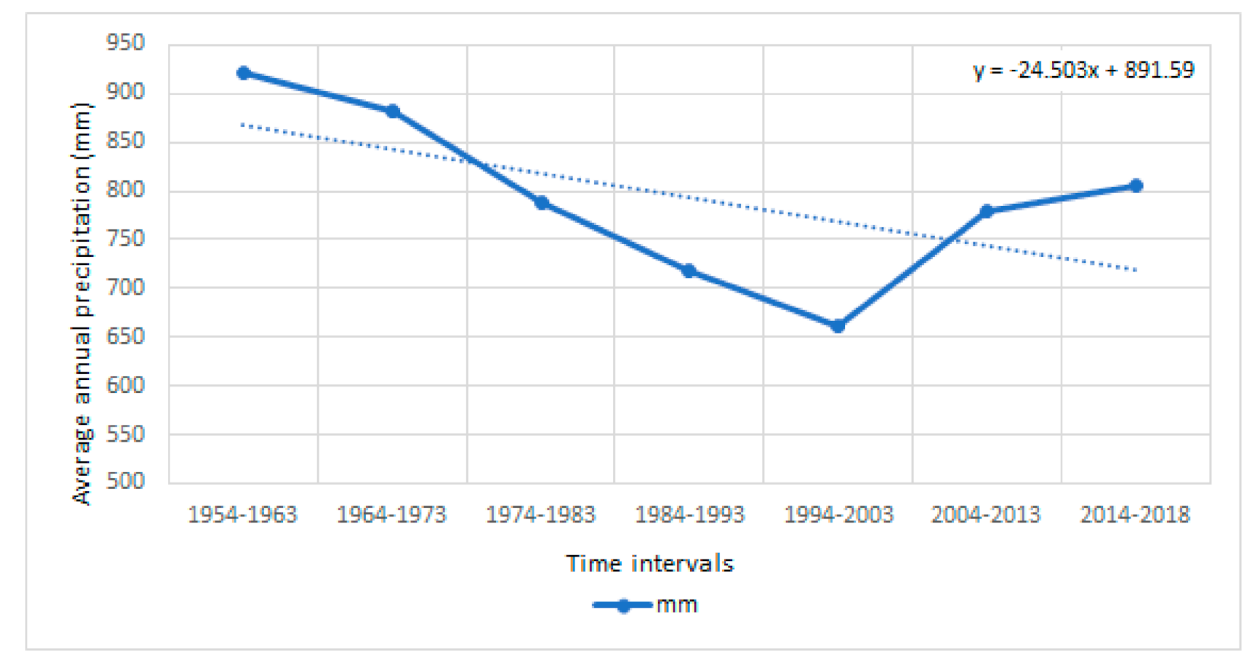

Figure 12. Average annual precipitation over 10-year periods. The average annual precipitation decreases constantly from $921.82 \mathrm{~mm}$ /year to $661.56 \mathrm{~mm} /$ year $(28 \%)$ in the period 1954-2003, while a slight increase is recorded in the period 2004-2014.

Land use changes were deduced using two datasets for 1994 and 2014 provided by the Geoportale della Regione Emilia-Romagna, and the percentages of the major land use classes, according to the CORINE Land Cover, were calculated (Table 3). Arable lands and shrub and/or herbaceous vegetation associations were significantly reduced in the study area, by $>30 \%$, compared with the situation elucidated by the 1994 land use map, favouring a revegetation process. In fact, forest areas increased by $34 \%$ (Table 3), while areas with little or no vegetation slightly increased, by $5 \%$ (Figure 13 ).

Table 3. Land use change in the period 1994-2014 in the study area.

\begin{tabular}{ccccc}
\hline CODE & Land Use & $\left.\mathbf{1 9 9 4} \mathbf{( m}^{\mathbf{2}}\right)$ & $\mathbf{2 0 1 4} \mathbf{( m}^{\mathbf{2}} \mathbf{~}$ & $\boldsymbol{\Delta} \mathbf{( \% )}$ \\
\hline 11 & Urban fabric & 118,361 & 301,359 & $155 \%$ \\
12 & Industrial, commercial, and transport units & 99,964 & 100,606 & $1 \%$ \\
13 & Mine, dump, and construction sites & 225,865 & 224,716 & $-1 \%$ \\
14 & Artificial, non-agricultural vegetated areas & 66,297 & 74,995 & $13 \%$ \\
21 & Arable land & $3,182,080$ & $2,098,310$ & $-34 \%$ \\
22 & Permanent crops & 159,478 & 365,372 & $129 \%$ \\
23 & Pastures & 14,033 & 517,243 & $3586 \%$ \\
31 & Forest & $1,861,610$ & $2,497,780$ & $34 \%$ \\
32 & Shrubs and/or herbaceous & $1,862,140$ & $1,195,760$ & $-36 \%$ \\
33 & vegetation associations & $1,254,490$ & $1,320,920$ & $5 \%$ \\
51 & Open spaces with little or no vegetation & 71,782 & 119,043 & $66 \%$ \\
\hline
\end{tabular}

The increase in the vegetation cover confirms a gradual stabilisation of the badland slopes over time and is in line with results of the analysis of the detailed maps of the vegetation cover and land use of the territory of the Salse di Nirano Natural Reserve-with a surface area of approximately 75,000 $\mathrm{m}^{2}$ - of 1973 and 2006. In 1973, areas with no vegetation and sparse and discontinuous herbaceous cover accounted for approximately $15 \%$ of the total area, while in 2006 they were reduced to less than $5 \%$. Arable lands were 
significantly reduced, by $62 \%$, while the forest cover increased significantly from $7.5 \%$ in 1973 to $37 \%$ in 2006 , tending to encompass the surrounding areas adjacent to badlands. In general, the forests are in a juvenile state, mostly originated by the abonnement of agriculture or iterated cutting in the past century. In 2006, different typologies of grassy plants covered the ground, such as Agropyron pungens, Podospermum canum and Aster linosyris, stabilising the slope and limiting the water erosion. Subsequently, bushes and shrubs have taken root (e.g., Spartium junceum, Rosa canina, Prunus spinosa, and Cornus sanguinea), which present strong root systems and make the slope more stable. Arboreal plants have also colonised the slopes, such as Quercus pubescens, Ulmus minor and Fraxinus ornus [119]. This trend is coincident with the institution in 1982 of the Regional Natural Reserve of Salse di Nirano, and with the resulting land use restrictions and regulations implemented for the area (Figure 14).
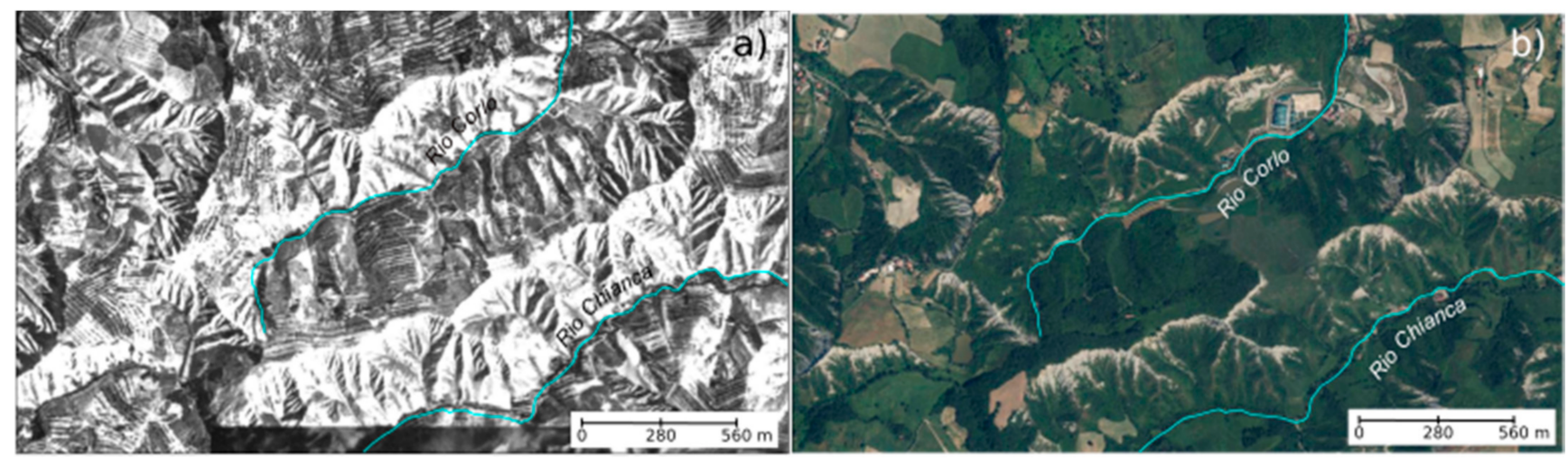

Figure 13. Land use change occurred in a sector of the study area over a 50-year period. (a) IGMI, GAI 1954 aerial photo and (b) orthophotos TeA of 2014. Despite the images' different resolution, the increase in forest cover and the reduction of agricultural lands are evident.
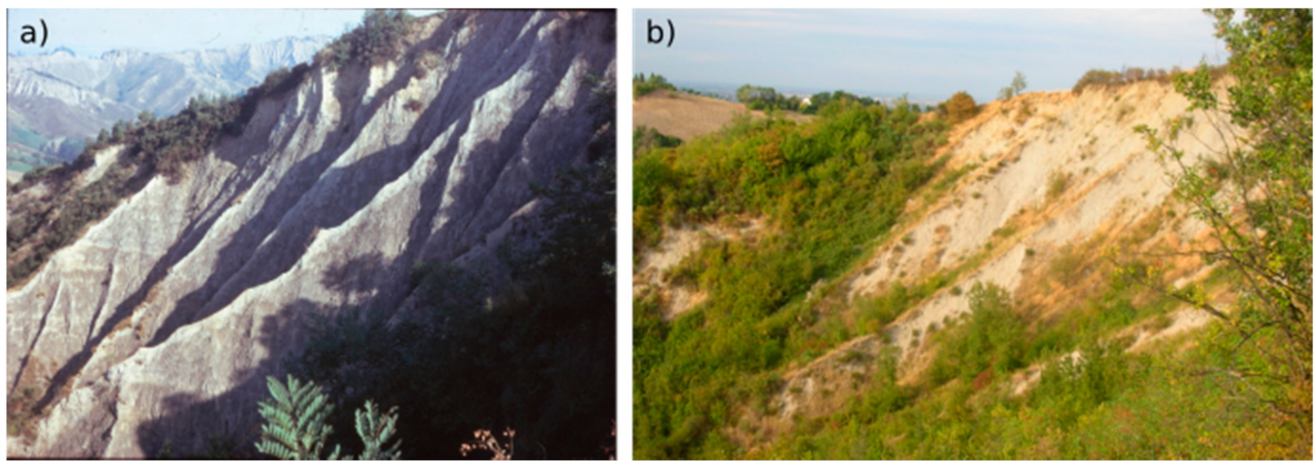

Figure 14. Vegetation change occurred in badland n. 26 between the late 1980s (a) and 2006 (b) (photos: (a) M. Panizza; (b) M. Bedetti).

\section{Discussion and Conclusions}

The investigation conducted in the study area allowed the identification and assessment of the areal and temporal changes of badlands over the last 40 years. In total, 55 Type A badlands were identified and digitalised, together with their stream network. Badlands are more extensively developed on SW and S-facing slopes, representing $69 \%$ of the total badlands. The presence of two main families of nearly perpendicular tectonic discontinuities, roughly parallel and orthogonal to the anticline axis, is likely to have influenced the distribution of the badland slopes. In fact, the $60 \%$ of badlands is aligned along an ENEWSW direction, while the remaining $40 \%$ is aligned along a NW-SE direction. The drainage density and the direct bifurcation ratio for the years 1973 and 2014 were calculated; both decreased over time, showing a decreasing erosion rate for the ground. This trend was 
confirmed by the results of the multitemporal analysis of the orthophotos, which reveal a reduction of the bare surface area from $6187.1 \mathrm{~m}^{2}$ in 1973 to $4214.1 \mathrm{~m}^{2}$ in 2014 due to an intensified revegetation process. The area reduction of the badlands observed for the study area is related to the land-cover changes, mainly due to agricultural activities, that occurred from the 1970s onwards. These consist essentially of a significant increase in more-protective land use types such as forests, permanent crops and pastures. This is particularly significant in the badlands located within the Regional Natural Reserve of Salse di Nirano, where the land use restrictions and regulations implemented along with its institution in 1982 has played a predominant role in badland evolution. In fact, the lack of typical management practices, such as regular mowing activities, and the reduction of arable lands due to their progressive abandonment have contributed to favouring revegetation on the badland slopes. The pluviometric variation during the period 1954-2018 likely favoured increase in revegetation processes, even if further analysis of pluviometric data (e.g., annual number of consecutive dry and wet days and annual spell length of dry and wet days spells) as well as temperature variation are needed.

The stabilisation trend of the badland area in the study area is in line with the results of research carried out in the Northern Apennines by Bosino et al. [101], who observed that $73 \%$ of badlands show a decrease in average area of ca. $34 \%$ over a 40 -year period, caused by a combination of natural and anthropic processes. The authors state that the decrease of average annual precipitation and of agricultural activity (especially vineyards) and the increase of the forest cover caused a decrease in surface runoff, favouring revegetation process and a reduction of badland areas. Piccarreta et al. [66] show, as well, a decrease in degraded areas between 1955 to 2002 of about $28 \%$ for the areas around Pisticci, Aliano, and Craco, in southern Italy. This reduction is mainly due to the widespread badland remodelling for the durum wheat cultivation. The levelling of gully heads for the production of cereals and orchards is reported to be the contributing factor for a land degradation decrease from 1949 to 1986 in the Basilicata region (southern Italy) [66] as well. However, several studies carried out in areas of central and southern Apennines, characterised by comparable climatic condition, reported an intensification of erosional processes and an increase of degraded areas, both on short and long term. Within the Radicofani badlands of southern Tuscany (central Italy), Ciccacci et al. [120] describe an increase of the total area occupied by badlands between 1955 and 2006 accompanied by an intensification of erosion rate. These changes appear to be due to the markedly increase of intense agricultural practices by mechanical device through time. The anthropic pressure related to the mismanagement of agricultural practices for durum wheat cultivation, which has led to the reclamation of scrub lands and badlands, appears to have played a significant role in the increasing of soil erosion in some areas in Basilicata (Southern Italy) [67] as well. In fact, abandoned areas, previously devoted to sown ground cultivation, are affected by intense erosional processes especially when extreme rainy event occurs, and deep gullies and new badland channels can evolve rapidly [121]. Human activities, particularly pastures or arable lands, played an important role in land degradation in Sicily (Southern Italy) as well $[14,122]$. The human impact on land use changes has been credited as main triggering drivers causing in increased soil erosion in several areas of the central Mediterranean region [123-126].

Results from this study provide a first insight into badlands morphological changes through time in a sector of Apennines that has been poorly investigated, highlighting the evolutionary trend. Detailed field surveys to supplement and verify results obtained are ongoing. Moreover, future research for the quantification of the morpho-evolution rate through UAV-derived high-resolution digital elevation model comparison are planned.

Author Contributions: Conceptualization, P.C.; methodology, P.C.; software, C.P.; validation, P.C. and C.P.; formal analysis, P.C. and C.P.; investigation, P.C.; writing-original draft preparation, P.C. and C.P.; writing-review and editing, P.C.; supervision, P.C. All authors have read and agreed to the published version of the manuscript. 
Funding: This research was conducted with financial support of FAR 2020 program of the Chemical and Geological Science Department of University of Modena and Reggio Emilia.

Institutional Review Board Statement: Not applicable.

Informed Consent Statement: Not applicable.

Data Availability Statement: Not applicable.

Acknowledgments: The authors are grateful to anonymous referees for their useful comments and suggestions to improve the original draft.

Conflicts of Interest: The authors declare no conflict of interest.

\section{References}

1. Harvey, A. Badlands. In Encyclopedia of Geomorphology; Goudie, A., Ed.; Routledge: London, UK, $2004 ;$ pp. 45-47.

2. Cappadonia, C.; Coco, L.; Buccolini, M.; Rotigliano, E. From slope morphometry to morphogenetic processes: An integrated approach of field survey, geographic information system morphometric analysis and statistics in Italian badlands. Land Degrad. Dev. 2016, 27, 851-862. [CrossRef]

3. Bouma, N.A.; Imeson, A. Investigation of relationships between measured field indicators and erosion processes on badland surfaces at Petrer, Spain. Catena 2000, 40, 147-171. [CrossRef]

4. Kasanin-Grubin, M.; Bryan, R. Lithological properties and weathering response on badland hillslopes. Catena 2007, 70, 68-78. [CrossRef]

5. Battaglia, S.; Leoni, L.; Sartori, F. Mineralogical and grain size composition of clays developing calanchi and biancane erosional landforms. Geomorphology 2002, 49, 153-170. [CrossRef]

6. Bucciante, M. Sulla Distribuzione Geografica dei Calanchi in Italia. L'Universo 1922, 3, 585-605.

7. Rapetti, F.; Vittorini, S. La temperatura del suolo in due versanti contrapposti del preappennino argilloso toscano. Boll. Soc. Ital. Sci. Suolo 1975, 9, 9-25.

8. Alexander, D.E. I calanchi, accelerated erosion in Italy. Geography 1980, 65, 95-100.

9. Torri, D.; Bryan, R.B. Micropiping processes and biancana evolution in southest Tuscany, Italy. Geomorphology 1997, 20, 219-235. [CrossRef]

10. Buccolini, M.; Coco, L.; Cappadonia, C.; Rotigliano, E. Relationships between a new slope morphometric index and calanchi erosion in northern Sicily, Italy. Geomorphology 2012, 149-150, 41-48. [CrossRef]

11. Bollati, I.; Masseroli, A.; Mortara, G.; Pelfini, M.; Trombino, L. Alpine gullies system evolution: Erosion drivers and control factors. Two examples from the western Italian Alps. Geomorphology 2019, 327, 248-263. [CrossRef]

12. Buccolini, M.; Coco, L. The role of the hillside in determining the morphometric characteristics of "calanchi": The example of Adriatic central Italy. Geomorphology 2010, 191, 142-149. [CrossRef]

13. Caraballo-Arias, N.A.; Conoscenti, C.; Di Stefano, C.; Ferro, V. Testing GIS-morphometric analysis of some Sicilian badlands. Catena 2014, 113, 370-376. [CrossRef]

14. Brandolini, P.; Pepe, G.; Capolongo, D.; Cappadonia, C.; Cevasco, A.; Conoscenti, C.; Marsico, A.; Vergari, F.; Del Monte, M. Hillslope degradation in representative Italian areas: Just soil erosion risk or opportunity for development? Land Degrad. Dev. 2018, 29, 3050-3068. [CrossRef]

15. Vittorini, S. Osservazioni sull'origine e sul ruolo di due forme di erosione nelle argille: Calanchi e biancane. Boll. Soc. Geogr. Ital. $1977,10,25-54$.

16. Faulkner, H. Vegetation cover density variations and infiltration pattern on piped alkali sodic soils; implications for the modelling of overland flow in semi-arid areas. In Vegetation and Erosion; Thornes, J.B., Ed.; John Wiley and Sons Ltd.: Chichester, UK, 1990; pp. 317-346.

17. Moretti, S.; Rodolfi, G. A typical “calanchi” landscape on the Eastern Apennine margin (Atri, Central Italy): Geomorphological features and evolution. Catena 2000, 40, 217-228. [CrossRef]

18. Biondi, E.; Pesaresi, S. The badland vegetation of the northern-central Apennines (Italy). Fitosociologia 2004, 41, 155-170.

19. Regüés, D.; Guàrdia, R.; Gallart, F. Geomorphic agents versus vegetation spreading as causes of badland occurrence in a Mediterranean subhumid mountainous area. Catena 2000, 40, 173-187. [CrossRef]

20. Howard, A.D. Badlands. In Geomorphology of Desert Environments; Abrahams, A.D., Parsons, A.J., Eds.; Chapman and Hall: London, UK, 1994; pp. 213-242.

21. Gallart, F.; Pérez-Gallego, N.; Latron, J.; Catari, G.; Martínez-Carreras, N.; Nord, G. Short- and long-term studies of sediment dynamics in a small humid mountain Mediterranean basin with Badlands. Geomorphology 2013, 196, 242-251. [CrossRef]

22. Yair, A.; Lavee, H.; Bryan, R.B.; Adar, E. Runoff and erosion processes and rates in the Zion Valley Badlands, northern Negev, Israel. Earth Surf. Process. 1980, 5, 205-225. [CrossRef]

23. Alexander, D.E. Difference between «calanchi» and «biancane» badlands in Italy. In Badland Geomorphology and Piping; Bryan, R., Yair, A., Eds.; Geo Books: Norwich, UK, 1982; pp. 71-87. 
24. Harvey, A. The role of piping in the development of badlands and gully systems in south-east Spain. In Badland Geomorphology and Piping; Bryan, R., Yair, A., Eds.; Geo Books: Norwich, UK, 1982; pp. 317-335.

25. Imeson, A.C. Studies of erosion thresholds in semiarid areas: Field measurement of soil loss and infiltration in northern Morocco. Catena Suppl. 1983, 4, 79-89.

26. Sdao, G.; Simone, A.; Vittorini, S. Osservazioni geomorfologiche su calanchi e biancane in Calabria (Geomorphology observation of calanchi and biancane in Calabria). Geografia Fisica e Dinamica Quaternaria 1984, 7, 10-16.

27. Berndtsson, R. Spatial Hydrological Processes in a Water Resources Planning Perspective. An Investigation of Rainfall and Infiltration in Tunisia; Report No.1009; Department of Water Resources Engineering, Institute of Technology, University of Lund: Lund, Sweden, 1988; p. 315.

28. Alexander, D.E.; Calvo, A. The influence of lichens on slope processes in some Spanish Badlands. In Vegetation and Erosion: Process and Environments; Thornes, J.B., Ed.; John Wiley and Sons Ltd.: Chichester, UK, 1990; pp. 385-398.

29. McCloskey, G.L.; Wasson, R.J.; Boggs, G.; Douglas, M.M. Timing and causes of gully erosion in the riparian zone of the semi-arid tropical Victoria River, Australia: Management implications. Geomorphology 2016, 266, 96-104. [CrossRef]

30. Bryan, R.B.; Yair, A. Badland Geomorphology and Piping; Geo Books: Norwich, UK, 1982.

31. Campbell, I.A. Badlands and badlands gullies. In Arid Zone Geomorphology; Thomas, D.S.G., Ed.; Belhaven: London, UK, 1989; pp. 159-183.

32. Regüés, D.; Pardini, G.; Gallart, F. Regolith behaviour and physical weathering of clayey mudrock as dependent on seasonal weather conditions in a badland area at Vallcebre, Eastern Pyrenees. Catena 1995, 25, 199-212. [CrossRef]

33. Pardini, G.; Vigna Guidi, G.; Pini, R.; Regues, D.; Gallart, F. Structure and porosity of smectitic mudrocks as affected by experimental wetting-drying cycles and freezing-thawing cycles. Catena 1996, 27, 149-165. [CrossRef]

34. Torri, D.; Calzolari, C.; Rodolfi, G. Badlands in changing environments: An introduction. Catena 2000, 40, 119-125. [CrossRef]

35. Nadal-Romero, E.; Regüés, D. Geomorphological dynamics of subhumid mountain badland areas-Weathering, hydrological and suspended sediment transport processes: A case study in the Araguás catchment (Central Pyrenees) and implications for altered hydroclimatic regimes. Prog. Phys. Geogr. 2010, 34, 123-150. [CrossRef]

36. Dube, H.B.; Mutema, M.; Muchaonyerwa, P.; Poesen, J.; Chaplot, V. A Global Analysis of the Morphology of Linear Erosion Features. Catena 2020, 190, 104542. [CrossRef]

37. Vandekerckhove, L.; Poesen, J.; Wijdenes, D.O.; Nachtergaele, J.; Kosmas, C.; Roxo, M.; De Figueiredo, T. Thresholds for gully initiation and sedimentation in Mediterranean Europe. Earth Surf. Process. 2000, 25, 1201-1220. [CrossRef]

38. Martínez-Casasnovas, J.A.; Antón-Fernández, C.; Ramos, M.C. Sediment production in large gullies of the Mediterranean area (NE Spain) from high-resolution digital elevation models and geographical information systems analysis. Earth Surf. Process. 2003, 28, 443-456. [CrossRef]

39. Poesen, J.; Nachtergaele, J.; Verstraeten, G.; Valentin, C. Gully Erosion and Environmental Change: Importance and Research Needs. Catena 2003, 50, 91-133. [CrossRef]

40. Müller-Nedebock, D.; Chaplot, V. Soil carbon losses by sheet erosion: A potentially critical contribution to the global carbon cycle: Soil Carbon Erosion by Sheet Erosion. Earth Surf. Process. Landf. 2015, 40. [CrossRef]

41. Vanwalleghem, T.; Poesen, J.; Nachtergaele, J.; Verstraeten, G. Characteristics, controlling factors and importance of deep gullies under cropland on loess-derived soils. Geomorphology 2005, 69, 76-91. [CrossRef]

42. De Santisteban, L.M.; Casalí, J.; Lopez, J.J. Assessing soil erosion rates in cultivated areas of Navarre (Spain). Earth Surf. Process. Landf. 2006, 31, 487-506. [CrossRef]

43. Nadal-Romero, E.; Martínez-Murillo, J.F.; Vanmaercke, M.; Poesen, J. Scale-dependency of sediment yield from badlands areas in Mediterranean environments. Prog. Phys. Geogr. Earth Environ. 2011, 35, 297-332. [CrossRef]

44. Gallart, F.; Marignani, M.; Pérez-Gallego, N.; Santi, E.; Maccherini, S. Thirty years of studies on badlands, from physical to vegetational approaches. A succinct review. Catena 2013, 106, 4-11. [CrossRef]

45. Boardman, J.; Favis-Mortlock, D.; Foster, I. A 13-year record of erosion on badland sites in the Karoo, South Africa. Earth Surf. Process. Landf. 2015, 40, 1964-1981. [CrossRef]

46. Migoń, P. Geoturystyka; Wydawnictwo Naukowe PWN: Warsaw, Poland, 2012.

47. Palacio-Prieto, J.L.; Rosado-González, E.; Ramírez-Miguel, X.; Oropeza-Orozco, O.; CramHeydrich, S.; Ortiz-Pérez, M.A.; Figueroa-Mah-Eng, J.M.; Fernández de Castro-Martínez, G. Erosion, culture and geoheritage; the case of Santo Domingo Yanhuitlán, Oaxaca, México. Geoheritage 2016, 8, 359-369. [CrossRef]

48. Zgłobicki, W.; Poesen, J.; Cohen, M.; Del Monte, M.; García-Ruiz, J.M.; Ionita, I.; Niacsu, L.; Machová, Z.; Martín-Duque, J.F.; Nadal-Romero, E.; et al. The potential of permanent gullies in Europe as geomorphosites. Geoheritage 2017, 11, 217-239. [CrossRef]

49. Bollati, I.; Vergari, F.; Del Monte, M.; Pelfini, M. Multitemporal dendrogeomorphological analysis of slope instability in upper Orcia valley (Southern Tuscany, Italy). Geogr. Fis. Dinam. Quat. 2016, 39, 105-120.

50. Poesen, J.; Valentin, C. Gully erosion and global change-Preface. Catena 2003, 50, 87-89. [CrossRef]

51. Li, Y.; Poesen, J.; Valentin, C. Gully Erosion under Global Change; Sichuan Science Technology Press: Chengu, China, 2004.

52. Valentin, C.; Poesen, J.; Li, Y. Gully erosion: Impacts, factors and control. Catena 2005, 63, 132-153. [CrossRef]

53. Martínez-Murillo, J.F.; Nadal-Romero, E. Perspectives on Badland Studies in the Context of Global Change. In Badlands Dynamics in a Context of Global Change; Nadal-Romero, E., Martínez-Murillo, J.F., Kuhn, N.J., Eds.; Elsevier: Amsterdam, The Netherlands, 2018; pp. 1-25. 
54. Dramis, F.; Gentili, B.; Coltorti, M.; Cherubini, C. Geological observations on badlands in the Marche region. Geogr. Fis. Dinam. Quat. 1982, 5, 38-45.

55. Phillips, C.P. The Crete Senesi, Tuscany. A vanishing landscape? Landscape Urban Plann. 1998, 41, 19-26. [CrossRef]

56. Clarke, M.L.; Rendell, H.M. The impact of the farming practice of remodelling hillslope topography on badlands morphology and soil erosion processes. Catena 2000, 40, 229-250. [CrossRef]

57. Buccolini, M.; Gentili, B.; Materazzi, M.; Aringoli, D.; Pambianchi, G.; Piacentini, T. Human impact and slope dynamics evolutionary trends in the monoclinal relief of Adriatic area of central Italy. Catena 2007, 71, 96-109. [CrossRef]

58. Gallart, F. Algunos criterios topográficos para identificar el origen antrópico decárcavas. Cuadernos Investig. Geogr. 2009, 35, 215-221. [CrossRef]

59. Keay-Bright, J.; Boardman, J. The influence of land management on soil erosion in the Sneeuberg Mountains, Central Karoo, South Africa. Land Degrad. Dev. 2007, 18, 423-439. [CrossRef]

60. Torri, D.; Santi, E.; Marignani, M.; Rossi, M.; Borselli, L.; Maccherini, S. The recurring cycles of biancana badlands: Erosion, vegetation and human impact. Catena 2013, 106, 22-30. [CrossRef]

61. Vergari, F.; Della Seta, M.; Del Monte, M.; Barbieri, M. Badlands denudation "hot spots": The role of parental material properties on geomorphic processes in 20 years monitored sites of Southern Tuscany (Italy). Catena 2013, 106, 31-41. [CrossRef]

62. Poesen, J. Soil erosion in the Anthropocene: Research needs. Earth Surf. Process. 2017, 43, 64-84. [CrossRef]

63. Vandaele, K.; Poesen, J.; Govers, G.; Van Wesemael, B. Geomorphic threshold conditions for ephemeral gully incision. Geomorphology 1996, 16, 161-173. [CrossRef]

64. Garcia-Ruiz, J.M.; White, S.M.; Làsanta, T.; Marti, C.; Gonzalez, C.; Paz Errea, M.; Valero, B. Assessing the effects of land-use changes on sediment yield and channel dynamics in the central Spanish Pyrenees. IAHS Publ. 1997, 245, 151-158.

65. Vandekerckhove, L.; Poesen, J.; Oostwoud Wijidenes, D.; Figueiredo, T. Topographical threshold for ephemeral gully initiation in intensively cultivated areas of the Mediterranean. Catena 1998, 33, 271-292. [CrossRef]

66. Piccarreta, M.; Capolongo, D.; Boenzi, F.; Bentivenga, M. Implications of decadal changes in precipitation and land use policy to soil erosion in Basilicata, Italy. Catena 2006, 65, 138-151. [CrossRef]

67. Capolongo, D.; Pennetta, L.; Piccarreta, M.; Fallacara, G.; Boenzi, F. Spatial and temporal variations in soil erosion and deposition due to land-levelling in a semi-arid area of Basilicata (southern Italy). Earth Surf. Process. Landf. 2008, 33, 364-379. [CrossRef]

68. García-Ruiz, J.M.; Lana-Renault, N. Hydrological and Erosive Consequences of Farmland Abandonment in Europe, with Special Reference to the Mediterranean Region-A Review. Agric. Ecosyst. Environ. 2011, 140, 317-338. [CrossRef]

69. Arnáez, J.; Lasanta, T.; Errea, M.P.; Ortigosa, L. Land abandonment, landscape evolution, and soil erosion in a Spanish Mediterranean mountain region: The case of Camero Viejo. Land. Degrad. Dev. 2011, 22, 537-550. [CrossRef]

70. Lukey, B.; Sheffield, J.; Bathurst, J.; Hiley, R.A.; Mathys, N. Test of the SHETRAN technology for modelling the impact of reforestation on badlands runoff and sediment yield at Draix, France. J. Hydrol. 2000, 235, 44-62. [CrossRef]

71. Vallauri, D.; Aronson, J.; Barbero, M. An analysis of forest restoration 120 years after reforestation on badlands in the Southwestern Alps. Restor. Ecol. 2002, 10, 16-26. [CrossRef]

72. Castaldi, F.; Chiocchini, U. Effects of land use changes on badland erosion in clayey drainage basins, Radicofani, Central Italy. Geomorphology 2012, 169-170, 98-108. [CrossRef]

73. Ballesteros-Canovas, J.A.; Stoffel, M.; Martín-Duque, J.F.; Corona, C.; Lucía, A.; Bodoque, J.M.; Montgomery, D.R. Gully evolution and geomorphic adjustments of badlands to reforestation. Sci. Rep. 2017, 7, 45027. [CrossRef] [PubMed]

74. Renschler, C.S.; Mannaerts, C.; Diekkrüger, B. Evaluating spatial and temporal variability in soil erosion risk-Rainfall erosivity and soil loss ratios in Andalusia, Spain. Catena 1999, 34, 209-225. [CrossRef]

75. Torri, D.; Regües-Muñoz, D.; Pellegrini, S.; Bazzoffi, P. Within-storm soil surface dynamics and erosive effects of rainstorms. Catena 1999, 38, 131-150. [CrossRef]

76. Mannaerts, C.M.; Gabriels, D. A probabilistic approach for predicting rainfall soil erosion losses in semiarid areas. Catena 2000, 40, 403-420. [CrossRef]

77. Archibold, O.W.; Lévesque, L.M.J.; Boer, D.H.; Aitken, A.E.; Delanoy, L. Gully retreat in a semi-urban catchment in Saskatoon, Saskatchewan. Appl. Geogr. 2003, 23, 261-279. [CrossRef]

78. Boardman, J.; Parsons, A.J.; Holland, R.; Holmes, P.J. Development of badlands and gullies in the Sneeuberg, Great Karoo, South Africa. Catena 2003, 50, 165-184. [CrossRef]

79. Øygarden, L. Rill and gully development during extreme winter runoff event in Norway. Catena 2003, 50, 217-242. [CrossRef]

80. Vergari, F.; Della Seta, M.; Del Monte, M.; Fredi, P.; Palmieri, E.L. Long-and short-term evolution of several Mediterranean denudation hot spots: The role of rainfall variations and human impact. Geomorphology 2013, 183, 14-27. [CrossRef]

81. Del Monte, M. The typical Badlands Landscape between the Tyrrhenian Sea and Tiber River. In Landscape and Landforms of Italy; World Geomorphological Landscapes; Soldati, M., Marchetti, M., Eds.; Springer: Cham, Switzerland, 2017 ; pp. $281-291$.

82. Castiglioni, B. Osservazioni sui calanchi appenninici. Boll. Soc. Geol. Ital. 1933, 52, 357-360.

83. Rodolfi, G.; Frascati, F. Cartografia di base per la programmazione in aree marginali (area rappresentativa dell'alta Vadera): Memorie illustrative della carta geomorfologica. Annali dell'Istituto Sperimentale per lo Studi e la Difesa del Suolo 1979, 10, 37-80.

84. Biancotti, A.; Cortemiglia, G.C. Morphogenetic evolution of the river system of southern Piedmont (Italy). Geogr. Fis. Dinam. Quat. 1982, 5, 10-13. 
85. Del Prete, M.; Bentivenga, M.; Coppola, L.; Rendell, H. Aspetti evolutivi dei reticoli calanchivi a sud di Pisticci. Geol. Romana 1994, 30, 295-306.

86. Calzolari, C.; Ungaro, F. Geomorphic features of a badland (biancane) area (Central Italy): Characterisation, distribution and quantitative spatial analysis. Catena 1998, 31, 237-256. [CrossRef]

87. Farabegoli, E.; Agostini, C. Identification of Calanco, a badland landform in the northern Apennines, Italy. Earth Surf. Process. Landf. 2000, 25, 307-318. [CrossRef]

88. Battaglia, S.; Leoni, L.; Rapetti, F.; Spagnolo, M. Dynamic evolution of badlands in the Roglio basin (Tuscany, Italy). Catena 2011, 86, 14-23. [CrossRef]

89. Ciccacci, S.; Galiano, M.; Roma, M.A.; Salvatore, M.C. Morphological analysis and erosion rate evaluation in badlands of Radicofani area (Southern Tuscany-Italy). Catena 2008, 74, 87-97. [CrossRef]

90. Della Seta, M.; Del Monte, M.; Fredi, P.; Palmieri, E.L. Space-time variability of denudation rates at the catchment and hillslope scales on the Tyrrhenian side of Central Italy. Geomorphology 2009, 107, 161-177. [CrossRef]

91. Clarke, M.L.; Rendell, H.M. Climate-driven decrease in erosion in extant Mediterranean badlands. Earth Surf. Process. Landf. 2010, 35, 1281-1288. [CrossRef]

92. Piccarreta, M.; Caldara, M.; Capolongo, D.; Boenzi, F. Holocene geomorphic activity related to climatic change and human impact in Basilicata, Southern Italy. Geomorphology 2011, 128, 137-147. [CrossRef]

93. Buccolini, M.; Coco, L. MSI (morphometric slope index) for analyzing activation and evolution of calanchi in Italy. Geomorphology 2013, 191, 142-149. [CrossRef]

94. Bollati, I.; Della Seta, M.; Pelfini, M.; Del Monte, M.; Fredi, P.; Lupia Palmieri, E. Dendrochronological and geomorphological investigations to assess water erosion and mass wasting processes in the Apennines of Southern Tuscany (Italy). Catena 2012, 90, 1-17. [CrossRef]

95. Caraballo-Arias, N.A.; Conoscenti, C.; Di Stefano, C.; Ferro, V. A new empirical model for estimating calanchi Erosion in Sicily, Italy. Geomorphology 2015, 231, 292-300. [CrossRef]

96. Coco, L.; Cestrone, V.; Buccolini, M. Geomorphometry for studying the evolution of small basins: An example in the Italian Adriatic foredeep. In Geomorphometry for Geosciences; Jasiewicz, J., Zwoliński, Z., Mitasova, H., Hengl, T., Eds.; Bogucki Wydawnictwo Naukowe, Adam Mickiewicz University in Poznań-Institute of Geoecology and Geoinformation, International Society for Geomorphometry: Poznań, Poland, 2015; pp. 107-110.

97. Aucelli, P.P.C.; Conforti, M.; Della Seta, M.; Del Monte, M.; D’uva, L.; Rosskopf, C.M.; Vergari, F. Multi-temporal digital photogrammetric analysis for quantitative assessment of soil erosion rates in the Landola catchment of the Upper Orcia Valley (Tuscany, Italy). Land Degrad. Dev. 2016, 27, 1075-1092. [CrossRef]

98. Bianchini, S.; Del Soldato, M.; Solari, L.; Nolesini, T.; Pratesi, F.; Moretti, S. Badland susceptibility assessment in Volterra municipality (Tuscany, Italy) by means of GIS and statistical analysis. Environ. Earth Sci. 2016, 75, 889. [CrossRef]

99. Caraballo-Arias, N.A.; Ferro, V. Are calanco landforms similar to river basins? Sci. Total Environ. 2017, 603-604, 244-255. [CrossRef] [PubMed]

100. Caraballo-Arias, N.A.; Ferro, V. Assessing, measuring and modelling erosion in calanchi areas: A review. J. Agric. Eng. 2016, 47, 181-190. [CrossRef]

101. Bosino, A.; Omran, A.; Maerker, M. Identification, characterization and analysis of the Oltrepo Pavese Calanchi in the northern Apennines, Italy. Geomorphology 2019, 340, 53-66. [CrossRef]

102. Provincia di Modena. PTCP. Piano Territoriale di Coordinamento Provinciale. Variante di Adeguamento in Materia di Dissesto Idrogeologico ai Piani di Bacino dei Fiumi Po e Reno; Area Programmazione e Pianificazione Territoriale: Modena, Italy, 2009.

103. Smiraglia, C.; Azzoni, R.S.; D’Agata, C.; Maragno, D.; Fugazza, D.; Diolaiuti, G.A. The evolution of the Italian glaciers from the previous data base to the New Italian Inventory. Preliminary considerations and results. Geogr. Fis. Dinam. Quat. 2015, 38, 79-87.

104. Köppen, W. Grundriß der Klimakunde, 2nd ed.; Walter de Gruyter and Co.: Berlin, Germany; Leipzig, Germany, 1931.

105. Gasperi, G.; Bettelli, G.; Panini, F.; Pizziolo, M. Note Illustrative della Carta Geologica d'Italia alla Scala 1: 50.000, Foglio 219 Sassuolo; S.EL.CA (Società Elaborazioni Cartografiche): Florence, Italy, 2005.

106. Regione Emilia-Romagna. Cartografia Geologica Online in Scala 1:10.000 della Regione Emilia-Romagna. 2017. Available online: https:/ / geo.regione.emilia-romagna.it/cartografia_sgss/user/viewer.jsp?service=geologia (accessed on 28 January 2021).

107. Boni, A.; Casnedi, R. Note Illustrative della Carta Geologica d'Italia alla Scala 1:100.000. Fogli 69 e 70 "Asti" e "Alessandria"; Servizio Geologico d'Italia: Rome, Italy, 1970; p. 83.

108. Tomadin, L. Ricerche sui Sedimenti Argillosi Fluviali dal Brenta al Reno. Giorn. Geol. 1969, 36, 1.

109. Horton, R.E. Erosional development of streams and their drainage basins: Hydrophysical approach to quantitative morphology. Geol. Soc. Am. Bull. 1945, 56, 275-370. [CrossRef]

110. Strahler, A. Dynamic Basis of Geomorphology. Geol. Soc. Am. Bull 1952, 63, 923-938. [CrossRef]

111. Avena, G.C.; Giuliano, G.; Palmieri, E.L. Sulla valutazione quantitativa della gerarchizzazione ed evoluzione dei reticoli fluviali. Boll. Soc. Geol. Ital. 1967, 86, 781-796.

112. Caloiero, D.; Mercuri, T. Le alluvioni in Basilicata dal 1921 al 1980; CNR-IRPI, Geodata 16: Cosenza, Italy, 1982.

113. Buffoni, L.; Maugeri, M.; Nanni, T. Precipitation in Italy from 1833-1996. Theor. Appl. Climatol. 1999, 63, 33-40. [CrossRef]

114. Brunetti, M.; Maugeri, M. Variations of Temperature and Precipitation in Italy from 1866 to 1995. Theor. Appl. Clim. 2000, 65, 165-174. [CrossRef] 
115. Brunetti, M.; Maugeri, M.; Monti, F.; Nanni, T. Temperature and precipitation variability in Italy in the last two centuries from homogenised instrumental time series. Int. J. Clim. 2006, 26, 345-381. [CrossRef]

116. Giorgi, F.; Lionello, P. Climate change projections for the Mediterranean region. Glob. Planet Chang. 2008, 63, 90-104. [CrossRef]

117. Pavan, S.; Zheng, Z.; Berg, P.; Lotti, C.; Giovanni, C.; Borisova, M.; Lindhout, P.; Jong, H.; Ricciardi, L.; Visser, R.; et al. Map- vs homology-based cloning for the recessive gene ol-2 conferring resistance to tomato powdery mildew. Euphytica 2008, 162, 91-98. [CrossRef]

118. Lionello, P.; Abrantes, F.F.; Gacic, M. The climate of the Mediterranean region: Research progress and climate change impacts. Reg. Environ. Chang. 2014, 14, 1679-1684. [CrossRef]

119. Dallai, D.; Del Prete, C. Gli Ambienti delle Salse: Problemi di Tutela della Biodiversità Vegetale. In Proceedings of the Convegno Internazionale "I Vulcani di Fango", Modena, Italy, 9-10 June 2007.

120. Ciccacci, S.; Galiano, M.; Roma, M.A.; Salvatore, M.C. Morphodynamics and morphological changes of the last 50 years in a badland sample area of Southern Tuscany (Italy). Z. Geomorphol. 2009, 53, 273-297. [CrossRef]

121. Piccarreta, M.; Capolongo, D.; Miccoli, M.N.; Bentivenga, M. Global change and long-term gully sediment production dynamics in Basilicata, southern Italy. Environ. Earth Sci. 2012, 67, 1619-1630. [CrossRef]

122. Cappadonia, C.; Conoscenti, C.; Rotigliano, E. Monitoring of erosion on two calanchi fronts-Northern Sicily (Italy). Landf. Anal. 2011, 17, 21-25.

123. García-Ruiz, J.M.; Lasanta, T.; Ruiz-Flaño, P.; Ortigosa, L.; White, S.; González, C.; Martí, C. Land-use changes and sustainable development in mountain areas: A case study in the Spanish Pyrenees. Landsc. Ecol. 1996, 11, 267-277. [CrossRef]

124. Molinillo, M.; Lasanta, T.; García-Ruiz, J.M. Managing mountainous degraded landscapes after farmland abandonment in the Central Spanish Pyrenees. Environ. Manag. 1997, 21, 587-598. [CrossRef] [PubMed]

125. Gómez-Gutiérrez, A.; Schnabel, S.; Lavado-Contador, F. Gully erosion, land use and topographical thresholds during the last 60 years in a small rangeland catchment in SW Spain. Land. Degrad. Dev. 2009, 20, 535-550. [CrossRef]

126. Lesschen, J.P.; Cammeraat, E.L.H.; Nieman, T. Erosion and terrace failure due to agricultural land abandonment in semi-arid environment. Earth Surf. Process. Landf. 2008, 33, 1574-1584. [CrossRef] 